\title{
Rates of nitrogen and growth retardant trinexapac-ethyl on wheat
}

\author{
Doses de nitrogênio e do redutor de crescimento trinexapac-etil na cultura do trigo
}

\author{
Marcelo Curitiba Espindula ${ }^{\mathrm{I}}$ Valterley Soares Rocha" ${ }^{\mathrm{II}}$ Leandro Torres de Souza ${ }^{\mathrm{II}}$

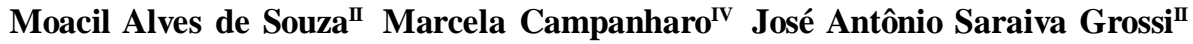

\begin{abstract}
The objective in this study was to evaluate the effects of nitrogen rates in association with rates of the growth retardant trinexapac-ethyl on wheat. The experiment was conducted in Viçosa, MG and arranged in a $5 \times 4$ factorial, randomized block design, with four repetitions. A combination of five nitrogen rates $\left(30,60,90,120\right.$ and $\left.150 \mathrm{~kg} \mathrm{ha}^{-1}\right)$ with four rates of trinexapac-ethyl $\left(0,62.5,125\right.$ and $\left.187.5 \mathrm{~g} \mathrm{ha}^{-1}\right)$ were tested. Trinexapac-ethyl promotes reduction of soot dry mass and grain yield at the lowest $N$ rates, but at the highest $N$ rates there is increase in these characteristics. The combination between $N$ and trinexapac-ethyl rates that promotes higher shoot dry mass is $150 \mathrm{~kg} \mathrm{ha}^{-1}$ and $187 \mathrm{~g} \mathrm{ha}^{-1}$ but that promotes higher grain yield is $100 \mathrm{~kg} \mathrm{ha}^{-1}$ and $120 \mathrm{~g} \mathrm{ha}^{-1}$, respectively.
\end{abstract}

Key words: Triticum aestivum, plant height, lodging, grain yield.

\section{RESUMO}

O objetivo neste estudo foi avaliar os efeitos de doses de nitrogênio associadas às doses do redutor de crescimento trinexapac-etil na cultura do trigo. O experimento, conduzido em Viçosa-MG, seguiu um esquema fatorial $5 \times 4$, no delineamento experimental de blocos casualizados, com quatro repetições. Os tratamentos foram 30, 60, 90, 120 e $150 \mathrm{~kg} \mathrm{ha}^{-1}$ de N, combinados com 0, 62,5, 125 e 187,5g ha-1 de trinexapac-etil. Trinexapac-etil promove redução da massa seca da parte aérea e do rendimento de grãos nas menores doses de $N$, mas sob doses elevadas de $N$ o trinexapac-etil promove aumento dessas características. A combinação entre doses de $N$ e trinexapac-etil que promove maior massa seca da parte aérea é de $150 \mathrm{~kg} \mathrm{ha}^{-1}$ e $187 \mathrm{~g} \mathrm{ha}^{-1}$, mas a que promove maior produção de grãos é de $100 \mathrm{~kg} \mathrm{ha}^{-1}$ e $120 \mathrm{~g} \mathrm{ha}^{-1}$, respectivamente.

Palavras-chave: Triticum aestivum, altura de plantas, acamamento, rendimento de grãos.

\section{INTRODUCTION}

Nitrogen fertilization has significantly contributed to higher cereal yields. However, the efficiency and/or the response of wheat (Triticum aestivum L.) genotypes to nitrogen application, in relation to grain yield, depend, among other factors, on the rates of the applied nitrogen (FREITAS et al., 1995). The use of increasingly higher $\mathrm{N}$ rates to increase yield leads to high vegetative growth, which causes plant lodging, affecting yield and grain quality, negatively. (BUZETTI et al., 2006).

Plant lodging can be reduced with the use of resistant cultivars, application of smaller amounts of nitrogen or use of growth retardants, among others techniques. Growth retardants reduce plant size and allow better nutrient utilization because of the physiological changes it causes in plants (BUZETTI et al., 2006).

Growth retardants are natural or synthetic chemicals that can be applied directly on plants. This

IEmpresa Brasileira de Pesquisa Agropecuária, Embrapa Rondônia, BR 364, km 5,5, 76815-800, Porto Velho, RO, Brasil. E-mail: marceloespindula@cpafro.embrapa.br. Autor para correspondência.

"Departamento de Fitotecnia, Universidade Federal de Viçosa (UFV), Viçosa, MG, Brasil.

IIIDepartamento de Fisiologia Vegetal, UFV, Viçosa, MG, Brasil.

${ }^{\text {IV }}$ Departamento de Fitotecnia, Universidade Estadual do Norte Fluminense Darcy Ribeiro (UENF), Campos dos Goytacazes, RJ, Brasil. 
practice changes structural and vital processes by altering the plant hormonal balance, aiming to increase production, improve quality or facilitate harvest (MATEUS et al., 2004). Among growth retardant, trinexapac-ethyl has been recently released in Brazil and studied in wheat (T. aestivum L.) (ESPINDULA et al., 2009b; ESPINDULA et al., 2010b; SOUZA, et al., 2010), rice (Oryza sativa L.) (ALVAREZ et al., 2007), soybean (Glycine max L.) (LINZMEYER JUNIOR et al., 2008), sugarcane (Saccharum sp L.) (LEITE et al., 2008, VIANA et al., 2008), among other crops. This compound is an acyl-cyclohexanedione derivative that inhibits 2-oxoglutarate-dependent dioxygenases in step 3 of gibberellin biosynthesis (SRIVASTAVA, 2002). Acylcyclohexanediones, such as trinexapac-ethyl ester, are structurally similar to 2-oxoglutarate and are therefore inhibitors of the dioxygenase activity by competition for binding sites on the 2-oxoglutarate co-substrate (RADEMACHER, 2000).

The combination of trinexapac-ethyl and increased nitrogen rate can be effective in increasing yield in wheat. The increase in plant height provided by nitrogen is counterbalanced by the use of the retardant, and the combination of these factors is a strategy to avoid lodging and to achieve higher yields
(ZAGONEL et al., 2002). It is necessary however to establish the adequate rates of nitrogen and trinexapacethyl for each cultivar and crop system, because height and architecture as well as physiological answer of wheat cultivars are different. The objective in this study was to evaluate the effects of nitrogen levels in combination with rates of the growth retardant trinexapac-ethyl on wheat.

\section{MATERIAL AND METHODS}

The experiment was conducted at the Experimental Station Prof. Diogo Alves de Mello, Universidade Federal de Viçosa - UFV, Viçosa-MG $\left(20^{\circ} 45^{\prime} \mathrm{S}\right.$ and $42^{\circ} 51^{\prime} \mathrm{W}, 650 \mathrm{~m}$ altitude), from June to October 2006. Daily data of the temperature (maximum, average and minimum), pluvial precipitation and air relative humidity mean throughout the experiment were provided by the climatologic station of the Department of Agricultural Engineering of the UFV (Figure 1).

The trial was installed in an area that has been cropped with soybean (summer) and wheat (winter) in the four last years. The soil of the experimental area is classified as Argissolo VermelhoAmarelo (EMBRAPA, 2006). Soil chemical analysis of

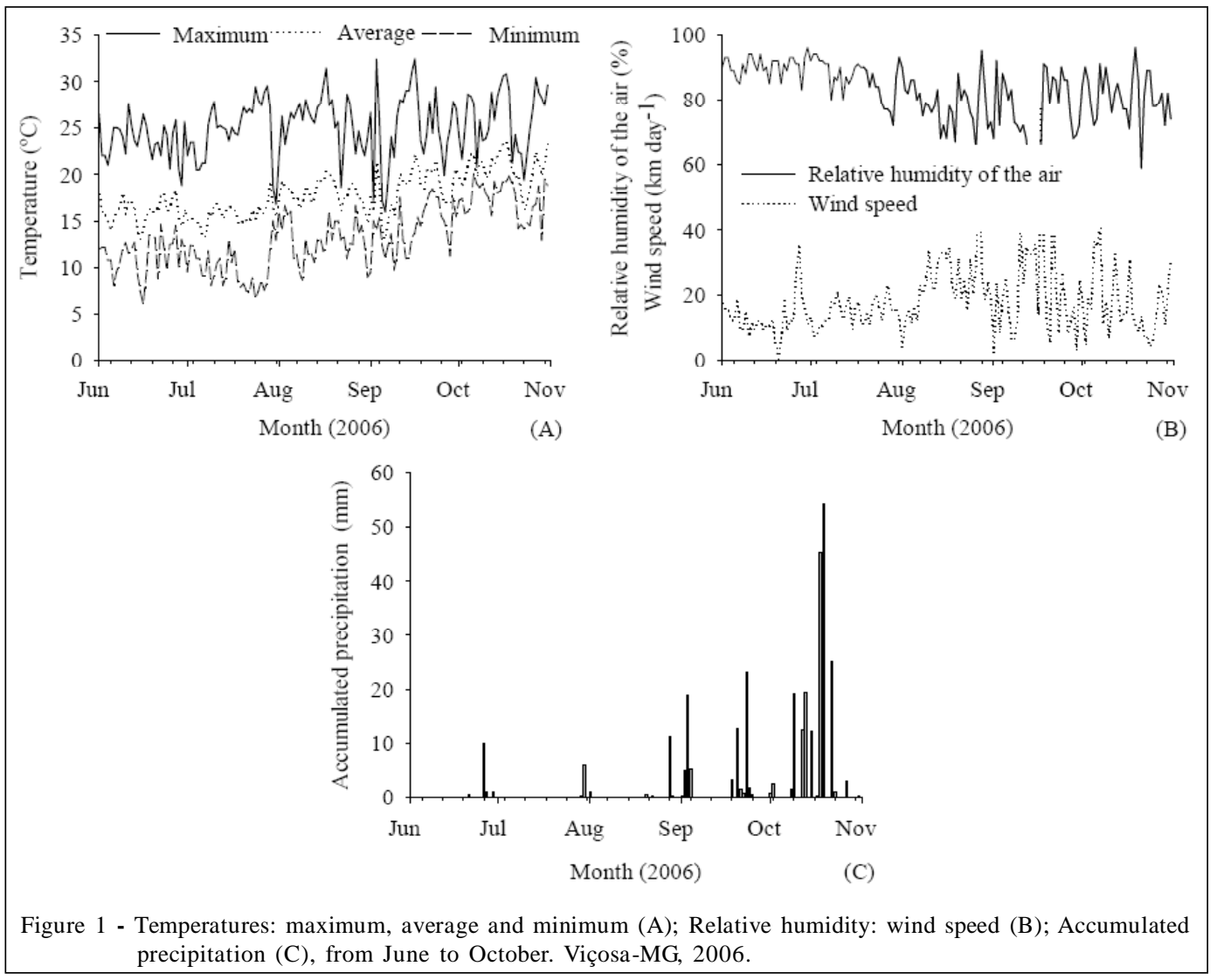

Ciência Rural, v.41, n.12, dez, 2011. 
the 0-0.20 m layer showed the following characteristics: $\mathrm{pH}=5.6 ; \mathrm{P}=22.9 \mathrm{mg} \mathrm{dm}^{-3} ; \mathrm{K}^{+}=105 \mathrm{mg} \mathrm{dm}^{-3} ; \mathrm{Ca}^{2+}=2.3 \mathrm{cmol}_{\mathrm{c}}$ $\mathrm{dm}^{-3} ; \mathrm{Mg}^{2+}=0.5 \mathrm{cmol}_{\mathrm{c}} \mathrm{dm}^{-3} ; \mathrm{Al}^{3+}=0 \mathrm{cmol}_{\mathrm{c}} \mathrm{dm}^{-3}$; $\mathrm{H}+\mathrm{Al}=3.47 \mathrm{cmol}_{\mathrm{c}} \mathrm{dm}^{-3}$; base saturation $(\mathrm{V})=47 \%$ and organic matter $(\mathrm{OM})=17.3 \mathrm{~g} \mathrm{~kg}^{-1}$. Soil preparation consisted of plowing followed by two disk harrowing and fertilization with $250 \mathrm{~kg} \mathrm{ha}^{-1}$ of a 8-28-16 applied in pre-sowing and additional nitrogen as required by the treatment, using ammonium sulphate as a source.

The experiment was arranged in a $5 \times 4$ factorial scheme, in a randomized complete block design, with four replications. The treatments consisted of five $\mathrm{N}$ rates $\left(30,60,90,120\right.$ and $\left.150 \mathrm{~kg} \mathrm{ha}^{-1}\right)$ combined with four rates of the growth retardant trinexapac-ethyl (4-cyclopropyl (hydroxy) methylene-3,5-carboxylate dioxa-cyclohexane ethyl) $\left(0,62.5,125\right.$ and $\left.187.5 \mathrm{~g} \mathrm{ha}^{-1}\right)$. Each plot consisted of seven rows of 5-m length spaced $0.18 \mathrm{~m}$ between rows. The usable plot area $\left(2.2 \mathrm{~m}^{2}\right)$ was formed by the three rows' center, with $0.5 \mathrm{~m}$ on each end of the plot left as border. Sowing density was 350 useful seeds $\mathrm{m}^{-2}$.

Wheat cultivar 'Pioneiro', with intermediate height and moderate resistance to lodging, was used in the trials. The total nitrogen rate was applied at sowing. The growth retardant was applied at stage 8 of the scale Feeks and Large, with the plants having the second node already formed. Retardant applications were carried out using a $\mathrm{CO}_{2}$ backpack sprayer, at constant pressure of $2.5 \mathrm{bar} \mathrm{pol}^{-2}$, with two 0.5 -m spaced fan nozzles (XR 110-015). A volume of 150L ha-1 of growth retardant solution was applied. The crop managements were realized according to crop' technical recommendations.

In the physiologic maturation phase of the grains it was obtained the following characteristics: Plant lodging, determined by direct measurement of the lodged area (plants with plus of 45 degrees of inclination in relationship to vertical) within the usable plot, followed by transformation to percentage of lodged area, in relation to total area. Plant height, recorded for fifteen randomly selected plants per plot, from collar to ear apex, didn't include awns.

Thousand-grain mass was determined in eight replications of 100 grains and the hectoliter mass using an appropriate scale, both with grains from plants of the usable area. Ear number per square meter was determined by direct count in three segments of 1 meter randomly selected in the usable area. Grain number per ear, shoot dry mass and harvest index (grain yield/shoot dry mass ratio, both with $0 \%$ moisture) were determined from 100 plants sequentially harvested in the central row of the plot. Grain yield (corrected to $13 \%$ moisture) was determined using grains from plants of the usable area and transformed to $\mathrm{kg} \mathrm{ha}^{-1}$.
Data were subjected to analysis of variance. The characteristics influenced by nitrogen rates or growth retardants were subjected to regression analysis and the characteristics simultaneously influenced by two factors were analyzed by response surface. In all cases, the mathematical models were chosen according to the best fitting equations and confirmed by the largest coefficients of determination $\left(\mathrm{r}^{2} / \mathrm{R}^{2}\right)$, significance of the regression coefficients ( $\mathrm{Bi}$ ) and the regression's F test, both at $5 \%$ rate. The significance of the regression coefficients was shown in the equation, admitting * and $* *$ as significant at 5 and $1 \%$, respectively.

\section{RESULTS AND DISCUSSION}

Plant lodging $(\hat{\mathrm{Y}}=-4.7051+0.3719 * \mathrm{~N}$ $\left.0.1480 * \mathrm{TE} ; \mathrm{R}^{2}=0.81 ; \mathrm{CV}=65.14 \%\right)$ and plant height $\left(\hat{\mathrm{Y}}=87.9071+0.1003 * \mathrm{~N}-0.1072 * \mathrm{TE} ; \mathrm{R}^{2}=0.94 ; \mathrm{CV}=2.95 \%\right)$ showed linear increase with increasing $\mathrm{N}$ rates and linear decrease with increasing trinexapac-ethyl rates (Figures 2A and B).

Increase in plant lodging in response to $\mathrm{N}$ rates corroborates the results reported for oat (NAKAGAWA et al., 2000). The rise in $\mathrm{N}$ supply stimulates vegetative growth (BUZETTI et al., 2006), reduces tissue hardness and, among other agronomic effects, contributes to increase in grain yield (COELHO et al., 1998; TEIXEIRA FILHO et al., 2007). These combined factors contribute to plant lodging, which is caused by low stem resistance, greater mass of mature ears and winds.

The decrease of lodging in wheat in response to trienexapac-ethyl occurred because growth retardants decrease the height plants by reducing internode length (ESPINDULA et al., 2010b) and increasing stem diameter (BERTI et al., 2007; FIALHO et al., 2009). The combination of these two effects results in increased plant mechanical strength and reduced lodging potential. Therefore, trinexapac-ethyl minimizes the lodging caused by high $\mathrm{N}$ rates applied on wheat.

The linear increase in plant height as a function of $\mathrm{N}$ rates are in line with findings reported for wheat (ZAGONEL \& FERNANDES, 2007), rice (BUZETTIet al., 2006) and millet (Panicum miliaceum L.) (SORATTO et al., 2007). Nitrogen is known to stimulate vegetative growth and stem elongation. Linear decrease in plant height was also reported by ZAGONEL \& FERNANDES (2007) for wheat cultivars treated with trinexapac-ethyl $\left(0,31.2,62.5,93.7,125.0\right.$ and $\left.156.2 \mathrm{~g} \mathrm{ha}^{-1}\right)$. This decrease in plant height may have been caused by the action of trinexapac-ethyl in reducing cell elongation in plant tissues by blocking the biosynthesis of gibberellic acid (HECKMAN et al., 2002). 

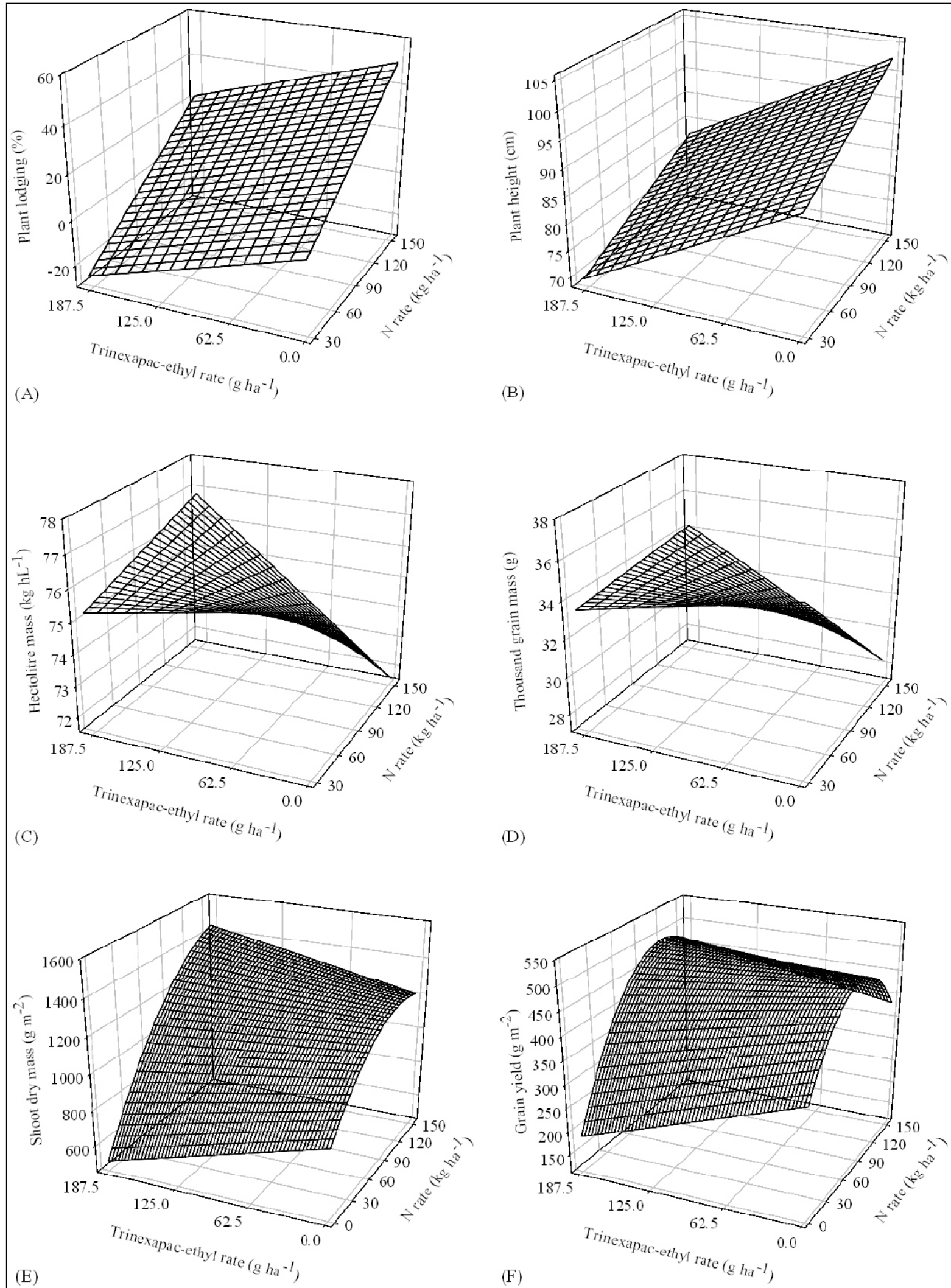

Figure 2 - Plant lodging (A), plant height (B), hectolitre mass (C), thousand grain mass (D), Shoot dry mass (E) and grain yield (F) of wheat plants subjected to different rates of nitrogen (N) and growth retardant trinexapac-ethyl. Viçosa, 2006. 
The hectolitre mass (HM) and thousand grain mass (TGM) had different responses regarding the level of a factor within the levels of another factor $(\hat{\mathrm{Y}}=77.54-0.0383 * \mathrm{~N}-0.0132 * * \mathrm{TE}+0.00027 * \mathrm{~N}$ TE; $\mathrm{R}^{2}=0.72 ; \mathrm{CV}=5.42 \%$ to $\mathrm{HM}$ and $\hat{\mathrm{Y}}=37.58-0.0605 * \mathrm{~N}-$ $0.0214 * \mathrm{TE}+0.000352 * \mathrm{NTE} ; \mathrm{R}^{2}=0.74 ; \mathrm{CV}=5.42$ to $\left.\mathrm{TGM}\right)$. At lower $\mathrm{N}$ rates, there was decrease in $\mathrm{HM}$ and TGM with increasing trinexapac-ethyl rates, but at higher $\mathrm{N}$ rates there was linear increase in these characteristics with increasing in trinexapac-ethyl rates. The response was similar when varying $\mathrm{N}$ levels within the levels of trinexapac-ethyl (Figures 1C and D). These results occurred because at lower $\mathrm{N}$ rates, the increase in retardant rates causes a decrease in leaf area and hence in the amount of photosynthates which compromises grain filling (ESPINDULA et al., 2009a). However, at higher $\mathrm{N}$ rates, the trinexapac-ethyl reduces lodging and increases the use of environmental resources, as a consequence of morphological changes in the canopy architecture of the plants (ZAGONEL \& FERNANDES, 2007; ESPINDULA et al., 2009b).

At lower rates of trinexapac-ethyl, $\mathrm{N}$ promotes excessive vegetative growth, resulting in selfshading, competition for photoassimilates (TRINDADE et al., 2006) and plant lodging (BUZETTI et al., 2006), leading to lower HM and TGM due to poor grain filling. Conversely, higher rates of the retardant minimize the harmful effects of increasing rates of $\mathrm{N}$.

The shoot dry mass (SDM) and grain yield showed a quadratic response to increasing $\mathrm{N}$ rates and a linear response to increasing trinexapac-ethyl rates $(\hat{\mathrm{Y}}=846.84+6.84 * \mathrm{~N}-0.02897 * \mathrm{~N} 2-1.8046 * \mathrm{TE}+0.02005 * \mathrm{~N}$ $\mathrm{TE} ; \quad \mathrm{R}^{2}=0.85 ; \quad \mathrm{CV}=11.74 \%$ to $\mathrm{SDM}$ and $\hat{\mathrm{Y}}=347.03+3.72 * \mathrm{~N}-.00229 * \mathrm{~N} 2-0.850 * \mathrm{TE}+0.0083 * \mathrm{NTE}$; $\mathrm{R}^{2}=0.78 ; \mathrm{CV}=7.08$ to grain yield). The nitrogen rate that promoted the highest SDM and grain yield varied with retardant rates. Trinexapac-ethyl promoted reduction of SDM and grain yield at the lowest $\mathrm{N}$ rates, but at the highest $\mathrm{N}$ rates there was increase in these characteristics. Maximum SDM $\left(1,447 \mathrm{~g} \mathrm{~m}^{-2}\right)$ was estimated for the combination $150 \mathrm{~kg} \mathrm{ha}^{-1} \mathrm{~N}$ and $187.5 \mathrm{~g}$ $\mathrm{ha}^{-1}$ trinexapac-ethyl, whereas maximum grain yield $\left(487 \mathrm{~g} \mathrm{~m}^{-2}\right)$ was estimated for $102.5 \mathrm{~kg} \mathrm{ha}^{-1} \mathrm{~N}$ and $120.71 \mathrm{~g}$ $\mathrm{ha}^{-1}$ trinexapac-ethyl (Figures $2 \mathrm{E}$ and F). The discrepancy between the SDM and yield maximum are due to sink restrictions. This is because above specified level, the sinks (grains) cease to accumulate photoassimilates. In this case, the plants vegetate but not convert photoassimilates produced in grain production.

The linear decrease of SDM, in response to rates of trinexapac-ethyl at lower $\mathrm{N}$ rates, suggests a reduction in plant development and grain filling, as a result of the decrease in leaf area index (data not shown). Reduction in SDM was also found for wheat 'IAPAR-53' treated with $125 \mathrm{~g} \mathrm{ha}^{-1}$ trinexapac-ethyl compared with nontreated plants (ZAGONEL et al., 2002). On the other hand, linear increases in dry weight at higher $\mathrm{N}$ rates are related to the lodging reduction promoted by the increase in trinexapac-ethyl rates.

The quadratic responses for the effects of $\mathrm{N}$ rates on grain yield show that the increase in nitrogen rates above a certain limit compromises yield by lodging and/or by excessive vegetative growth. Quadratic responses to increasing $\mathrm{N}$ rates were also reported for wheat (TRINDADEet al., 2006; ESPINDULA et al., 2010a). This behavior also indicates that increasing rates of trinexapac-ethyl moves the maximum yield point upwards, i.e., higher rates of the retardant allow the use of higher rates of $\mathrm{N}$.

The decrease in grain yield in response to trinexapac-ethyl at lower $\mathrm{N}$ rates did not agree with reports in the literature of quadratic responses and linear increases (ZAGONEL \& FERNANDES, 2007) or lack of significant effects (MATYSIAK, 2006). However, it is believed that this response is due to the lower photosynthetic capacity and lower reserve of assimilates in the stem for translocation during the grain filling. At larger $\mathrm{N}$ rates, the increase in grain yield with increasing retardant rates was similar to those reported byZAGONEL \& FERNANDES (2007). These responses were caused by reduced lodging (Figure 2A) and changes in plant height (Figure 2B) and plant architecture such as more compact and less decumbent leaves (ESPINDULA et al., 2009a), avoiding self-shading and increasing photosynthesis by capturing light energy.

The harvest index responded linearly to increasing trinexapac-ethyl rates and quadratically to increasing nitrogen rates $\left(X=0.449+0.001 * \mathrm{~N}+0.0000058 * \mathrm{~N}^{2}\right.$ and $\mathrm{X}=0.473+0.000079 * \mathrm{~N}^{2} ; \mathrm{R}^{2}=0.98$ and $0.96 ; \mathrm{CV}=3.43 \%$ ). The maximum harvest index, estimated at $86.20 \mathrm{~kg} \mathrm{ha}^{-1} \mathrm{~N}$, was 0.4921 (Figure 3A). The quadratic response was similar to that reported for the wheat cultivar 'EMBRAPA-22' in two years of cultivation (COELHO et al., 1998). This is because nitrogen applications promote increases in plant growth and reductions in harvest index, since increases in grain yield are proportionately smaller than the increase in vegetative growth (KOLCHINSKI \& SCHUCH, 2002). Thus, the increase in harvest index, up to $86.20 \mathrm{~kg} \mathrm{ha}^{-1} \mathrm{~N}$, may be related to the optimal rate range, whereas the decrease above this rate may be related to the abovementioned disproportion between yield and vegetative development.

The linear increase in harvest index with increasing trinexapac-ethyl rates was similar to that reported for the cultivar 'Alcover' (ZAGONEL \& FERNANDES, 2007). This is because the decrease in 

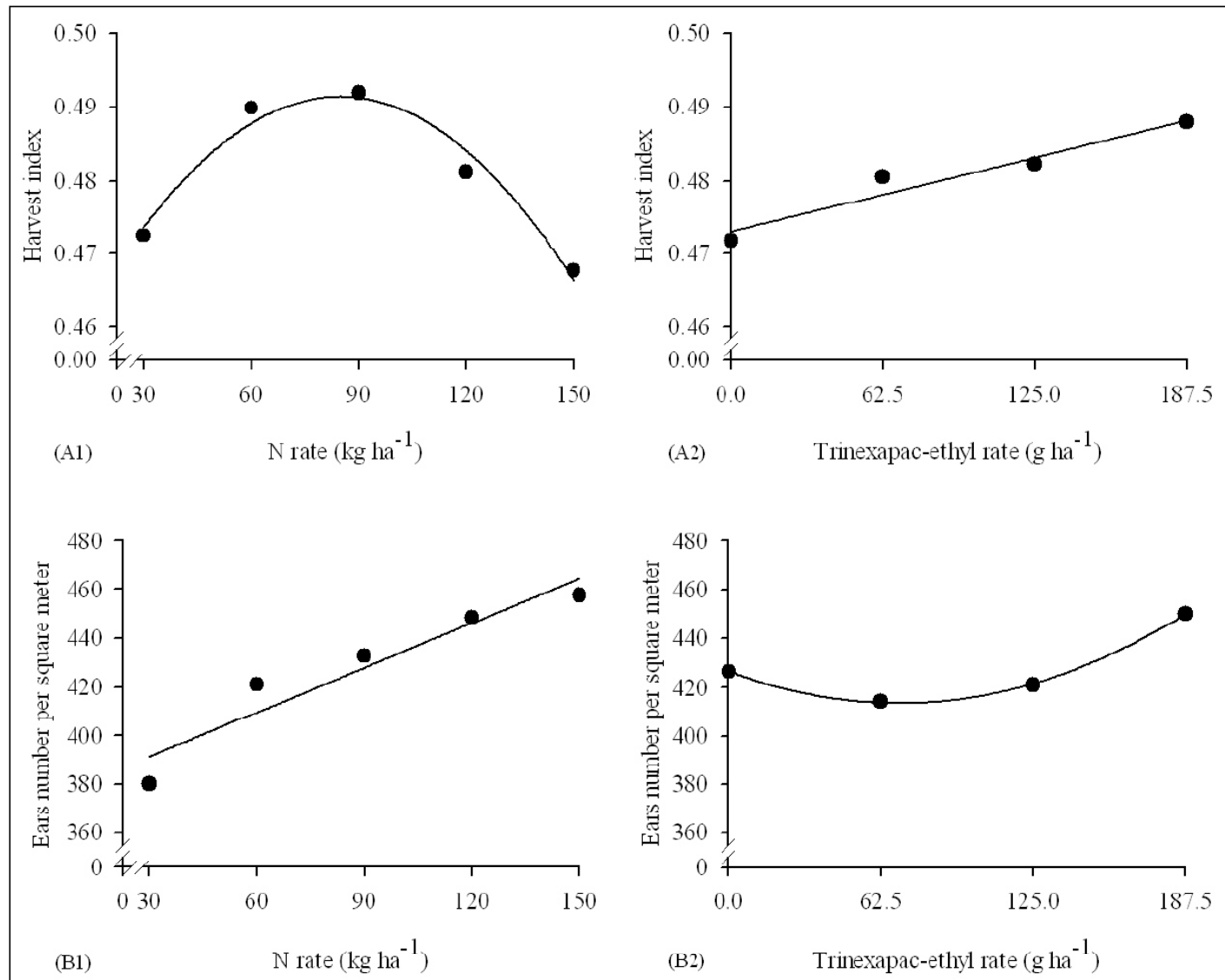

(B1)

$$
\mathrm{N} \text { rate }\left(\mathrm{kg} \mathrm{ha}^{-1}\right)
$$



Figure 3 - Harvest index (A1 and A2), ears number per square meter (B1 and B2) and grains number per ear (C) of wheat (cv. 'Pioneiro') in response to nitrogen or trinexapc-ethyl rates. Viçosa, 2006.

the length of stems and leaves (ESPINDULA et al., 2009a) promoted by the retardant rates leads to reduction in vegetative shoot mass.

The number of ears per $\mathrm{m}^{2}$ increased linearly with increasing nitrogen rates and responded quadratically to increasing trinexapac-ethyl rates $(\hat{\mathrm{Y}}=373.24+0.6079 * * \mathrm{~N}$ and $\hat{\mathrm{Y}}=426.51-$ $0.3684 * \mathrm{TE}+0.0026 * \mathrm{TE} 2 ; \mathrm{R}^{2}=0.95$ and $0.99 ; \mathrm{CV}=9.89 \%$ ), with the point of smallest number of ears per $\mathrm{m}^{2}(413.46$ ears per $\mathrm{m}^{2}$ ) at the rate of $70.84 \mathrm{~g} \mathrm{ha}^{-1}$ (Figure 3B). The increase, as a function of $\mathrm{N}$ rates, was due to greater tillering response to high nitrogen supply. Increase in density of rice panicles, as a function of $\mathrm{N}$ rates, was also found at 0 and $75 \mathrm{~kg} \mathrm{ha}^{-1}$ (MAUAD et al., 2003). It was expected, though, that increasing trinexapac-ethyl rates would lead to linear increase in the number of ears 
per $\mathrm{m}^{2}$ because of the greater light penetration and consequent stimulus to tiller development, but that did not happen. Thus, no biological explanation was apparent for the response of this characteristic.

The number of grains per ear (NGE) responded quadratically to increasing nitrogen rates $\left(\hat{\mathrm{Y}}=25.8055+0.2836 * * \mathrm{~N}-0.0011 * * \mathrm{~N}^{2} ; \mathrm{R}^{2}=0.98 ;\right.$ $\mathrm{CV}=7.48 \%$ ). The maximum NGE, estimated at $128.90 \mathrm{~kg}$ $\mathrm{ha}^{-1} \mathrm{~N}$, was 44.08 (Figure 3C). Lack of response was reported for four cultivars of wheat (TEIXEIRA FILHO et al., 2007), whereas linear growth was reported for wheat 'Pioneiro' or 'BRS 210' (ESPINDULA et al., 2010a). The increase observed up to the maximum rate may be related to the nutritional status of the plant at the time of vegetative meristem differentiation into reproductive and because there wasn't flowers and spikelets' abortion due to nutritional deficiency.

\section{CONCLUSION}

The use of trinexapac-ethyl in wheat 'Pioneiro' promotes reduction of shoot dry mass and grain yield at the lowest $\mathrm{N}$ rates, but at the highest $\mathrm{N}$ rates there is increase in these characteristics.

Increasing rates of trinexapac-ethyl moves the maximum shoot dry mass and yield point upwards. The combination between $\mathrm{N}$ and trinexapac-ethyl rates that promotes higher shoot dry mass is $150 \mathrm{~kg} \mathrm{ha}^{-1}$ and $187 \mathrm{~g}$ $\mathrm{ha}^{-1}$ but that the ones promotes higher grain yield is $100 \mathrm{~kg}$ $\mathrm{ha}^{-1}$ and $120 \mathrm{~g} \mathrm{ha}^{-1}$, respectively.

\section{ACKNOWLEDGEMENTS}

The authors would like to thank the Conselho Nacional de Desenvolvimento Científico e Tecnológico (CNPq) and Fundação de Amparo à Pesquisa do Estado de Minas Gerais (FAPEMIG) for the financial support and grants.

\section{REFERENCES}

ALVAREZ, R.C.F. et al. Influência do etil-trinexapac no acúmulo, na distribuição de nitrogênio $\left({ }^{15} \mathrm{~N}\right)$ e na massa de grãos de arroz de terras altas. Revista Brasileira de Ciência do Solo, Viçosa, v.31, p.1487-1496, 2007. Available from: <http:/ /www.scielo.br/pdf/rbcs/v31n6/25.pdf>. Accessed: Aug. 5, 2010.

BERTI, M. et al. Produtividade de cultivares de trigo em função do trinexapacethyl e doses de nitrogênio. Scientia Agraria, Curitiba, v.8, n.2, p.127-134, 2007. Available from: <http://ojs.c3sl.ufpr.br/ojs2/index.php/agraria/article/view/8376/6656>. Accessed: Apr. 12, 2011.

BUZETTI, S. et al. Resposta de cultivares de arroz a doses de nitrogênio e do regulador de crescimento cloreto de clormequat. Pesquisa Agropecuária Brasileira, Brasília, v.41, p.17311737, 2006. Available from: <http://www.scielo.br/pdf/pab/ v41n12/a07v4112.pdf>. Accessed: Jan. 21, 2010. doi: 10.1590/ S0100-204X2006001200007.
COELHO, M.A.O. et al. Resposta da produtividade de grãos e outras características agronômicas do trigo EMBRAPA-22 irrigado ao nitrogênio em cobertura. Revista Brasileira de Ciência do Solo, Viçosa, v.22, p.555-561, 1998.

EMBRAPA. Sistema brasileiro de classificação de solos. 2.ed. Rio de Janeiro, 2006. 306p.

ESPINDULA, M.C. et al. Effect of nitrogen and trinexapacethyl rates on the spad index of wheat leaves. Journal of Plant Nutrition, Philadelphia, v.32, n.11, p.1956-1964, 2009a. Available from: <http://apps.isiknowledge.com/ full_record.do?product=UA\&search_mode=GeneralSearch\&qid=16\&S $\mathrm{ID}=2 \mathrm{DkgdH} 9 \mathrm{k} 5 \mathrm{a} 1 \mathrm{n} @ 2 \mathrm{OAI} 6 \mathrm{e} \& \mathrm{page}=1 \& \mathrm{doc}=5 \&$ colname=WOS $>$. Accessed: Apr. 12, 2011.

ESPINDULA, M.C. et al. Use of growth retardants in wheat. Planta Daninha, Viçosa, v.27, p.379-387, 2009b. Available from: <http://www.scielo.br/pdf/pd/v27n2/22.pdf >. Accessed: Jan. 21, 2010. doi: 10.1590/S0100-83582009000200022.

ESPINDULA, M.C. et al. Doses e formas de aplicação de nitrogênio no desenvolvimento e produção da cultura do trigo. Ciência e Agrotecnologia, Lavras, v.34, n.6, p.1404-1411, 2010a. Available from: <http://www.scielo.br/pdf/cagro/v34n6/ 07.pdf> Accessed: Apr. 10, 2011. doi: 10.1590/S141370542010000600007 .

ESPINDULA, M.C. et al. Efeitos de reguladores de crescimento na elongação do colmo de trigo. Acta Scientiarum. Agronomy, Maringá, v.32, p.109-116, 2010b. Available from: <http:// periodicos.uem.br/ojs/index.php/ActaSciAgron/article/view/ 943/943>. Accessed: Aug. 5, 2010. doi: 10.4025/ actasciagron.v32i1.943.

FIALHO, C.M.T. et al. Caracteres morfoanatômicos de brachiaria brizantha submetida à aplicação de trinexapac-ethyl. Planta Daninha, Viçosa, v. 27, n. 3, p. 533-539, 2009. Available from: <http://www.scielo.br/pdf/pd/v27n3/14.pdf >. Accessed: Apr. 12, 2011.

FREITAS, J.G. et al. Eficiência e resposta de genótipos de trigo ao nitrogênio. Revista Brasileira de Ciência do Solo, Campinas, v.19, p.229-234, 1995.

HECKMAN, N.L. et al. Influence of trinexapac-ethyl on respiration of isolated wheat mitochondria. Crop Science, Madison v.42, p.423-427, 2002. Available from: <https:// www.crops.org/publications/cs/articles/42/2/423>. Accessed: Aug. 5, 2010. doi: 10.2135/cropsci2002.0423.

KOLCHINSKI, E.M.; SCHUCH, L.O.B. Produtividade e utilização de nitrogênio em aveia em função de épocas de aplicação do nitrogênio. Revista Brasileira de Agrociência, Pelotas, v.8, p.117-121, 2002. Available from: <http:// www.ufpel.tche.br/faem/agrociencia/v8n2/artigo06.pdf >. Accessed: Aug. 10, 2010.

LEITE, G.H.P. et al. Reguladores vegetais e qualidade tecnológica da cana-de-açúcar em meio de safra. Ciência e Agrotecnologia, Lavras, v.32, p.1843-1850, 2008. Available from: 〈http://www.scielo.br/pdf/cagro/v32n6/v32n6a24.pdf〉. Accessed: Aug. 10, 2010.

LINZMEYER JUNIOR, R. et al. Influência de retardante vegetal e densidades de plantas sobre o crescimento, acamamento e 
produtividade da soja. Acta Scientiarum. Agronomy, Maringá, v.30, p.373-379, 2008. Available from: <http:// periodicos.uem.br/ojs/index.php/ActaSciAgron/article/view/ 3547/2491>. Accessed: Aug. 10, 2010. doi: 10.4025/ actasciagron.v30i3.3547.

MATEUS, G.P. et al. Perdas de cloreto de mepiquat no algodoeiro por chuva simulada. Pesquisa Agropecuária Brasileira, Brasília, v.39, p.631-636, 2004. Available from: <http:// www.scielo.br/pdf/pab/v39n7/21304.pdf>. Accessed: Aug. 10, 2010.

MATYSIAK, K. Influence of trinexapac-ethyl on growth and development of winter wheat. Journal of Plant Protection Research, Poznan, v.46, p.133-143, 2006. Available from: $<$ http://www.plantprotection.pl/PDF/46\%282\%29/ JPPR_46\%282\%29_2_Matysiak.pdf $>$. Accessed: Aug. 10, 2010.

MAUAD, M. et al. Nitrogen and silicon fertilization of upland rice. Scientia Agricola, Piracicaba, v.60, p.761-765, 2003. Available from: 〈http://www.scielo.br/pdf/sa/v60n4/a23v60n4.pdf〉. Accessed: Aug. 10, 2010.

NAKAGAWA, J. et al. Adubação nitrogenada no perfilhamento da aveia-preta em duas condições de fertilidade do solo. Pesquisa Agropecuária Brasileira, Brasília, v.35, p.1071-1080, 2000. Available from: 〈http://www.scielo.br/pdf/pab/v35n6/4661.pdf〉. Accessed: Aug. 10, 2010.

RADEMACHER, W. Growth retardants: Effects on gibberellin bioproduction synthesis and other metabolic pathways. Annual Review Plant Physiology and Plant Molecular Biology, Mineapolis, v.51, p.501-531. 2000. Available from: <http:// arjournals.annualreviews.org/doi/pdf/10.1146/ annurev.arplant.51.1.501>. Accessed: Aug. 10, 2010. doi: 10.1146/annurev.arplant.51.1.501.

SORATTO, R.P. et al. Doses e épocas de aplicação de nitrogênio em cobertura na cultura do painço (Panicum miliaceum L.). Ciência e Agrotecnologia, Lavras, v.31, p.1661-1667, 2007. Available from:<http://www.scielo.br/pdf/ cagro/v31n6/a09v31n6.pdf>. Accessed: Aug. 10, 2010.
SOUZA, L.T. et al. Growth retardants in wheat and its effect in physiological quality of seeds. Ciência Rural, Santa Maria, v.40, p.1431-1434, 2010. Available from: <http://www.scielo.br/ pdf/cr/v40n6/a601cr2081.pdf>. Accessed: Aug. 10, 2010. doi: 10.1590/S0103-84782010000600031.

SRIVASTAVA, L.M. Plant growth and development: Hormones and environment. San Diego: Academic, 2002. 772p.

TEIXEIRA FILHO, M.C.M. et al. Resposta de cultivares de trigo irrigados por aspersão ao nitrogênio em cobertura na região do Cerrado. Acta Scientiarum. Agronomy, Maringá, v.29, p.421-425, 2007. Available from: <http://periodicos.uem.br/ ojs/index.php/ActaSciAgron/article/view/471/283>. Accessed: Aug. 10, 2010. doi: 10.4025/actasciagron.v29i3.471.

TRINDADE, M.G. et al. Nitrogênio e água como fatores de produtividade do trigo no cerrado. Revista Brasileira de Engenharia Agrícola e Ambiental, Campina Grande, v.10, p.24-29, 2006. Available from: <http://www.scielo.br/pdf/rbeaa/ v10n1/v10n1a04.pdf>. Accessed: Aug. 10, 2010.

VIANA, R.S. et al. Efeito da aplicação de maturadores químicos na cultura da cana de açúcar (Saccharum spp.) variedade SP813250. Acta Scientiarum. Agronomy, Maringá, v.30, p.6571, 2008. Available from: <http://periodicos.uem.br/ojs/ index.php/ActaSciAgron/article/view/1130/626>. Accessed: Aug. 10, 2010. doi: 10.4025/actasciagron.v30i1.1130.

ZAGONEL, J.; FERNANDES, E.C. Doses e épocas de aplicação do redutor de crescimento afetando cultivares de trigo em duas doses de nitrogênio. Planta Daninha, Viçosa, v.25, p.331339, 2007. Available from: <http://www.scielo.br/pdf/pd/v25n2/ a13v25n2.pdf $>$. Accessed: Aug. 10, 2010.

ZAGONEL, J. et al. Efeito de reguladores de crescimento na cultura de trigo submetido a diferentes doses de nitrogênio e densidades de plantas. Planta Daninha, Viçosa, v.20, p.471476, 2002. Available from: <http://www.scielo.br/pdf/pd/v20n3/ 19.pdf>. Accessed: Aug. 10, 2010. 